\title{
THE BIOLOGICAL EFFECTS AND TOXICITY OF TWO BIOINSECTICIDES AND FOUR BOTANICAL EXTRACTS AGAINST COTTON LEAFWORM, SPODOPTERA LITTORALIS (BOISDVAL) NOCTUIDAE: LEPIDOPTERA
}

\author{
S. A. Mahmoud \\ Plant Protection Research Institute, ARC. Giza Egypt. \\ E mail:Sobhy90@gmail.com
}

Received: Dec. 17, 2016

Accepted: Jan. 1, 2017

\begin{abstract}
The biological effects and toxicity of two microbial insecticides derived from Bacillus thuringiensis Berhiner (MVPa and MVPC) and four botanical extracts (Kochia indica, Curcuma zedoaria, Zygophyllum simplex and Sorghum bicolor) were studied on $6^{\text {th }}$ instar larvae of Spodoptera littoralis. The bioinsecticide MVPC and the botanical extract $Z$. simplex were the most toxic agents of all tested materials. Larval mortality percentages and that of larvae which failed to pupate increased by increasing concentrations. In addition, pupation percentages and emerged adults increased by increasing concentrations of the tested treatments. Morphological deformities were increased by increasing concentrations, which was observed in the stages of pupae and adults produced from the survived treated larvae.
\end{abstract}

Key words: Bacillus thuringiensis, Kochia indica, Curcuma zedoaria, Zygophyllum simplex and Sorghum bicolor, biopesticides.

\section{INTRODUCTION}

Microbial control agents are considered a good pesticides due to their usual narrow that range, absence of vertebrate toxicity or pathogenicity, compellability with beneficial organisms and biodegradability (Goettel, 1991). Several authors studied the susceptibility of different commercial bacterial formulations containing $B$. thuringiensis (El-Mandarawy,1992). Plant extracts were used as toxicants, repellents, synergists growth regulators or antifeedants of many insects (Ismail et al.,1996, Nassar et al.,1997 and 1999 and Salema, et al., 2003). The insecticidal activity of extracts of different plant species against many insects were studied by many authors (El-sayed, 1983, Salam, and Ahmed 1997, and Abdallah and Kandill, 1989 ).

The present study aims to study the toxicity of two bioinsecticides (MVPa and MVPc) and four botanical extracts (Kochia indica, Curcuma zedoaria, Zygophyllum simplex and Sorghum bicolor) on the $6^{\text {th }}$ larval instar of $S$. littoralis and the biological effects on the developing stages.

\section{MATERIALS AND METHODS \\ 1- Rearing of insects:}

The cotton leafworm, Spodoptera littoralis (Boisdval) was reared in the laboratory (Biological control Research Department at Plant Protection Research Institute) on castor bean leaves (Ricinus communis $L$.) according to the methods described by El-Defrawy et al., (1964) at 25 $\pm 2{ }^{\circ} \mathrm{C}$ and $65 \%$ R.H. and provide with the needed larvae for bioassay tests.

\section{2- The Bioinsecticides:}

Two commercial preparations derived from Bacillus thuringiensis and consisted of millions of bio0encapsulated flowable suspension were evaluated.

a- MVPa: contains delta endotoxin of Bacillus thuringiensis var Karstala as active ingredient of $20 \%$.

b- MVPc: contains delta endotoxin of Bacillus thuringiensis var. Azawi as active ingredient of $20 \%$. 
Six concentrations of $5,10,15,20,25$ and $30 \mathrm{ml} / 100 \mathrm{ml}$ water were prepared as a aqueous flowable suspensions, in addition to control.

\section{3- Botanical extraction treatments:}

Four botanical plants (Table 1) were collected to evaluate their extracts against cotton leaf worm, Spodoptera littoralis.

The plant leaves were grounded and soaked in distilled water for overnight, then filtered and the filtrations were dried using a Soxhlet apparatus. Crude extracts of different plants were dissolved in $100 \mathrm{ml}$ water at six concentrations of $5,10,15,20$, 25 and $30 \mathrm{ml} / 100 \mathrm{ml}$ water.

\section{4- Tests:}

The castor bean leaves were dipped in each concentration, then the leaves after drying were offered to $6^{\text {th }}$ instar Spodoptera littoralis larvae.

The following procedures were followed in all treatments:

1-Three replicates of ten larvae, putted in 15 $\mathrm{cm}$ Petri dish were fed on castor bean leaves treated with bioinsecticides and botanical extracts for a period of 48 hours. After treatments, the surviving larvae were fed on clean untreated castor bean leaves till pupation.

Mortalities were recorded daily. Also, the number of pupated larvae and emerged adults were observed.

2- Larvae were starved for 60 hours before introducing the treated food, in order to obtain rapid simultaneous ingestion of the offered food.

3- The control tests were conducted using castor bean leaves in water only and left to dry.

4- The experiments were carried out under laboratory conditions of $27 \pm 2 \stackrel{\circ}{-}$ and $65 \pm$ $5 \%$ R.H.

\section{Statistical analysis:}

The $\mathrm{LD}_{50}$ was determined according to Leora POLO -PC (Leora Software, 1994) and the data subjected to the Probit analysis (Finney, 1971) when necessary, while mortality percentages were adjusted across concentrations within the probit procedure by Abbott's formula (Abbott,1925).

\section{RESULTS AND DISCUSSION}

The obtained results of the two pesticides derived from Bacillus thuringiensis and the different botanical extracts Tables ( 2 \& 3 ) revealed a variation in their effectiveness against the $6^{\text {th }}$ instar larvae of Spodoptera littoralis.

\section{Percent of larval mortality:}

The obtained results in (Tables 2 \& 3 ) show that the rates of larval mortality ranged between 35 to $75 \%$ and 29 to $56 \%$ for concentrations of $5-30 \mathrm{ml} / 100 \mathrm{ml}$ water of the bioinsecticides $\mathrm{MVPa}$ and $\mathrm{MVPc}$, respectively. As for the botanical extracts of Kochia indica, Curcuma zedoaria, Zygophyllum simplex and Sorghum bicolor at concentrations of $5-30 \mathrm{ml} / 100 \mathrm{ml}$ water, the larval mortality ranged between $2-65$ $\%, 25-82 \%, 30-68 \%$ and $35-63 \%$, respectively.

From the obtained results, it appears that the percentage of larval mortality was directly proportional to the applied concentrations of the bioinsecticides and botanical extracts.

Results of bioinsecticides are similar to that observed by Pantanberkar et al.,(1997) who found that increasing concentrations of $B$. thuringiensis caused higher mortalities to neonate larvae of $P$. operculalla and Spodoptera littoralis to reach more than $85 \%$ at different concentrations. Moreover, Abou Bakr (1997) found that Fbrbae XL.V.EC.WP and EC was effective enough against $S$. littoralis even at higher concentrations.

As for the botanical extracts, Pandje et al., (1993) studied the compounds analysed from Curcuma zedoaria, C.K.pandwrata for insecticidal constituents agents $S$. littoralis and reported pronounced toxicity against 
neonate of $S$. littoralis in a contact residue bioassay irrespective of the larval stages. Also, Dadang and Ohsawa (1998) found that several Zingiberaceae species (Curcuma zedoaria, C. heyneana, C.

Table (1): The tested plant extracts

\begin{tabular}{|l|l|l|l|}
\hline \multicolumn{1}{|c|}{ English name } & Scientific name & Family & Part used \\
\hline Kochia & Kochia indica & Chenopodiaceae & leaves \\
\hline Curcuma & Curcuma zedoaria & Zingiberaceae & leaves \\
\hline Zygophyllum & Zygophyllum simplex & Zingiberaceae & leaves \\
\hline Sorghum & Sorghum bicolor & Meliaceae & leaves \\
\hline
\end{tabular}

Table (2): The delayed effects of two bioinsecticides against the $6^{\text {th }}$ instar larvae of Spodoptera littoralis and developmental stages

\begin{tabular}{|c|c|c|c|c|c|}
\hline $\begin{array}{l}\text { Concentrations } \\
\mathrm{ml} / 100 \mathrm{~m} \text { water }\end{array}$ & $\begin{array}{c}\text { larval } \\
\text { mortality \% }\end{array}$ & pupation\% & $\begin{array}{c}\text { deformed } \\
\text { pupae\% }\end{array}$ & $\begin{array}{c}\text { emerged } \\
\text { adults } \\
\%\end{array}$ & $\begin{array}{l}\text { deformed } \\
\text { adults } \%\end{array}$ \\
\hline \multicolumn{6}{|c|}{$\mathrm{MVPa}$} \\
\hline 5 & 35 & 55 & 2 & 7 & 1 \\
\hline 10 & 43 & 42 & 5 & 10 & 0 \\
\hline 15 & 44 & 36 & 20 & 0 & 0 \\
\hline 20 & 65 & 25 & 10 & 0 & 0 \\
\hline 25 & 42 & 48 & 10 & 0 & 0 \\
\hline 30 & 75 & 5 & 20 & 0 & 0 \\
\hline \multicolumn{6}{|c|}{ MVPc0 } \\
\hline 5 & 36 & 61 & 5 & 7 & 1 \\
\hline 10 & 29 & 67 & 3 & 1 & 0 \\
\hline 15 & 33 & 49 & 16 & 2 & 0 \\
\hline 20 & 45 & 33 & 22 & 0 & 0 \\
\hline 25 & 53 & 21 & 26 & 0 & 0 \\
\hline 30 & 65 & 10 & 25 & 0 & 0 \\
\hline control & 0 & 98 & 0 & 98 & 0 \\
\hline
\end{tabular}


Table (3): The delayed effects of four botanical extracts against the $6^{\text {th }}$ instar larvae of Spodoptera littoralis and developmental stages

\begin{tabular}{|c|c|c|c|c|c|}
\hline \\
\hline $\begin{array}{l}\text { Concentrations } \\
\mathrm{ml} / 100 \mathrm{~m} \text { water }\end{array}$ & $\begin{array}{c}\text { Larval } \\
\text { mortality \% }\end{array}$ & pupation\% & $\begin{array}{c}\text { deformed } \\
\text { pupae\% }\end{array}$ & $\begin{array}{c}\text { emerged } \\
\text { adults } \\
\%\end{array}$ & $\begin{array}{c}\text { deformed } \\
\text { adults } \%\end{array}$ \\
\hline Kochia indica & \multicolumn{5}{|c|}{ botanical extracts } \\
\hline 5 & 2 & 63 & 25 & 9 & 1 \\
\hline 10 & 25 & 35 & 30 & 8 & 2 \\
\hline 15 & 31 & 43 & 26 & 0 & 0 \\
\hline 20 & 39 & 35 & 26 & 0 & 0 \\
\hline 25 & 61 & 9 & 30 & 0 & 0 \\
\hline 30 & 65 & 2 & 33 & 0 & 0 \\
\hline \multicolumn{6}{|c|}{ Curcuma zedoaria } \\
\hline 5 & 27 & 8 & 9 & 9 & 1 \\
\hline 10 & 25 & 44 & 12 & 7 & 1 \\
\hline 15 & 39 & 35 & 21 & 5 & 0 \\
\hline 20 & 45 & 35 & 20 & 0 & 0 \\
\hline 25 & 56 & 36 & 8 & 0 & 0 \\
\hline 30 & 82 & 18 & 0 & 0 & 0 \\
\hline \multicolumn{6}{|c|}{ Zygophyllum simplex } \\
\hline 5 & 30 & 57 & 5 & 8 & 1 \\
\hline 10 & 38 & 54 & 14 & 7 & 1 \\
\hline 15 & 44 & 31 & 25 & 0 & 0 \\
\hline 20 & 55 & 45 & 0 & 0 & 0 \\
\hline 25 & 61 & 39 & 0 & 0 & 0 \\
\hline 30 & 68 & 32 & 0 & 0 & 0 \\
\hline \multicolumn{6}{|c|}{ Sorghum bicolor } \\
\hline 5 & 35 & 22 & 22 & 20 & 1 \\
\hline 10 & 40 & 22 & 22 & 5 & 1 \\
\hline 15 & 51 & 26 & 20 & 3 & 0 \\
\hline 20 & 57 & 21 & 21 & 0 & 0 \\
\hline 25 & 60 & 32 & 8 & 0 & 0 \\
\hline 30 & 63 & 36 & 1 & 0 & 0 \\
\hline control & 2 & 98 & 0 & 98 & 0 \\
\hline
\end{tabular}




\section{Pupation:}

At concentrations between 5 to $30 \mathrm{ml}$, the pupation percentages were ranged between $5-25 \%, 10067 \%, 2-63 \%, 8-36 \%$, $31-57 \%$ and $21-36 \%$, for MVPa, MVPc, Kochia indica, Curcuma zedoaria, Zygophyllum simplex and Sorghum bicolor, respectively (Tables $2 \& 3$ ).

These results show that the pupation percentages decreased by increasing the concentrations of different treatments.

\section{Deformation:}

The deformed pupae are the individual which had cuticle containing pupal parts with parts of last larval skin or those which were completely covered with pupal exuvia but the external characters of larvae. The deformed pupae died before completed the pupal period. The deformity of emerged adults was manifested as bent or twisted wings of adults. The deformation increased by increasing the concentrations of the different treatments.

Deformed pupae percentages at (Tables 2 \&3) as affected by the tested agents were ranged between $2-20 \%, 3-26 \%, 25-33$ $\%, 8-21 \%, 0-25 \%$ and $1-22 \%$ for MVPa, MVPc, Kochia indica, Curcuma zedoaria, Zygophyllum simplex and Sorghum bicolor, respectively at concentrations between 5 to $30 \mathrm{ml}$.

From these results, it is evident that the percent of larvae which failed to pupate increased by increasing the concentrations of the bioinsecticides and botanical extracts.

Similar effects was produced by $B$. thuringiensis against flour moth, Anagasta kuehniella (1991), Salam (1991) who reported similar findings on $P$. operculella when pupae developing from larvae treated with 100 ppm neem oil. In addition, Chanda and Chakravorty (1993) found deformed adult with a prolonged period of development were obtained from larvae of Corycyra cephalonica maintained on
(Azadirachtin, $0.03 \%$ ) observed crushed jowar (Sorghum) grains.

These findings agree with those of Dulmage and Martinez (1973) who reported that when the tobacco budworm Heliothis virescents larvae were continuously subjected to sublethal levels of deltaendotoxin of Bacillus thuringiensis. Many larvae failed to pupate whereas some others pupated but failed to emerge. In addition, these results are in harmony with those conducted by El-Mandarawy (1992) who controlled $P$. rapae larvae by the pesticide, bactospine. In addition Schmidt et al.,(1997) noticed that the larvae of $S$. littoralis and $A$. iposlion failed to pupate at higher concentrations of Melia azedarach extract. Nassar et al.,(1997) reported the occurrence of malformed larvae which failed to pupate at high concentrations of Nerium oleander and Sorghum bicolor extracts.

\section{Emerged adults:}

Results in Tables (2 \&3) show that the percent of emerged moths has been greatly affected and a gradual decrease has been achieved with bioinsecticides and botanical extracts treatments until adult emergence completely disappeared at high concentrations.

These findings are in agreement with those obtained by Salama et al., (2003) who found that Bacillus thuringiensis reduced adult emergence of the greasy decreased has been achieved with bioinsecticides and botanical extracts treatments until adult emergence from the cutworm $A$. ipsilon pupae. Also, Abdel-Halim (1993) showed that the various doses of dipel $2 x$ affected remarkably adult stages and the adult emergence was sharply decreased by the applied doses, as it ranged from $85 \%$ at 192 IU $\mathrm{ml}$ to $0 \%$ with the highest dose $6400 \mathrm{IU}$ $\mathrm{ml}$ IU ml. Salem et al., (1995) indicated that Melia leaves extract at high concentrations had a direct effect on emergence of adults and it was sufficient to increase mortality 
rate to $100 \%$. Moreover, Schmidt, et al., (1997) found that no adult of $S$. littoralis emerged from pupae that developed from larvae treated with 5\% Melia azedarach extract.

\section{REFERENCES}

Abbott, W. S. (1925). A method for computing the effectiveness of an insecticide. J. Econ. Entomol ., 18: 265 267.

Abdallah, M. D. and M. A. Kandil (1989). Bioactivity of plant extracts against Sitophilus granarius (L.) and Tribolium castanem (Hbst.). Bull. Ent. Soc. Egypt. Econ. Ser., 15: 199 - 204.

Abdel-Halim S.M.A. (1993). Bioactivity of dipel $2 x$ a commercial preparation of Bacillus thuringiensis Berhiner against the cotton Leaf worm, Spodoptera littoralis (Boisd.). Egypt. J. Agric. Res., 71 (1): $175-183$.

Abou-Bakr, H. (1997). Efficacy of different Bacillus thuringiensis formulations against the cotton Leaf worm, Spodoptera littoralis (Boisd.). Egypt. J. Biol. Pest Control 7 (1): $7-11$.

Chanda, S and S. Chakravorty (1993). Food with neem oil affects life and development of rice moth., Corcyra cephalonica (Stainton (Lepidoptera: Pyralidae). Entomol., 23 (2): 153- 156.

Dadang, S. Riyanto and K. Ohsawa (1998). Lethal antifeedant substance from rhizome Alinia galangal Sw. (Zingberaceae). Journal of Pesticide Science. 23 (3): 304 - 307.

Dulmage, H. T. and E. Martinery (1973). The effects of continuous exposure to low of concentrations delta0endotoin of Bacillus thuringiensis on the development of tobacco budworm Helthiolis virescens. J. Invert. Pathal. 22: 14022.

El-Defrawi, M. E., A. Toppozada, N. A. Mansour and M. Zeid (1964). Toxicological studies on the Egyptian cotton leafworm, Prodenia litura. I. Susceptibility of different larval instars to insecticides. J. Econ. Entomol. 57: 591593.

El-Mandarawy, H. B. R. (1992). Studies on the biological effects of Bacillus thuringiensis and gamma radiation on Pieris rapae L. M.Sc. Thesis. Fac. Sci. Cairo University.

El-Sayed, E. L. (1983). Evaluation of insecticidal properties of the common Indian Neem Azadirachta indica A. Juss, seeds against the cotton Leaf worm, Spodoptera littoralis (Boisd.) Bull. Ent. Soc. Egypt. Econ. Ser.,19820 : $39-47$.

Finney, D. J. (1971). Probit analysis. 3 rd, Cambridge University. Press, New York. $333 \mathrm{pp}$

Goettel, M. S. (1991). Evaluation of ricks and regulatory constaints in the commercialization and fecundity of Heliothis armigera. Acta Agricultural Universitatis Henanensis, 32 (4): 403 406.

Ismail, L. A., M. M. E. Saleh and H. M. Radwan (1996). Biological effects of fluctuations of natural enemies associated with Bemisia tabaci (Genn.) and (Boisd). Egyptian journal of Biological Pest control, 6 (10) : 71 - 74.

Leora Software (1994). POLO - PC Probit and Llogit analysis. Leora Software,

Nassar, M. I., M. K. Omnio and A. H. Mohye (1997). The potentially of Sorghum bicolor and Nerium oleaner extracts in the control of the Grey flesh fly , Parasarcophaga argyrostoma. J. Egypt. Ger. Soc.Zool. 22: 215 - 251.

Nassar, M. I., M. R. EL-Mandarawy and S. A. Abdel Samea (1999). Evaluation of two bioinsecticides and four botanical extracts against the sixth instar Phthorimaea operculella Zeller larvae. J. Egypt. Ger. Soc. 30 (A): 255 - 260.

Pantanberkar, U. S., S. N. Mukherjee and P. K. Ranjekar (1997). Laboratory screening of different Bacillus thuringiensis strain against certain Lepidopteran pests and subsequent field evaluation of the pod boring pests complex pigeon pea 
(Cahamus cajam ). Antonic-VanLceuwenhoek. 71 (4): 315 - 319.

Pandjl, C., C. Grimm, V. Wary, L. White and P. Proksch (1993). insecticidal constituents from four species of the Zingiberceae. Phytoshemist 34 (2): 415419.

Salema, H. A., M. M. Shershoby and F. A. Kwaiz (2003). Evaluation of some natural and chemical pesticides against the black cutworm, Agrotis ipsilon (Hufn.). J. Agric. Sci. Mansoura Univ., 28 (4): 3053 3059.

Salam, A. L. A. and A. A. I. Ahmed (1997). Evaluation of using the extracts of Chinaberry fruits, Melia azadarach L.in the control of the cotton leafworm, Spodoptera littoralis in Egypt. International Conference on pests in agriculture, France. 3: $1159-1162$.
Salam, N., I. A. Ismail and M. A. Gesraha (1995). Effect of Melia azadarach extract on the biology, food utilization and nutritional indices of Agrotis ipsilon (Hufn.). Egypt .Biol. Pest control. 5 (1): 15-19.

Salem, S. A. (1991). Evaluation of neem seed oil as tuber protectant against Phthorimaea operculella Zell. (Lepidoptera: Gelechiidae). Annals of Agric..Sci, Moshtohor. 29 (1): 587 - 595.

Schmidt, G. H., A. A. Ahmed and M. Breuer (1997). Effect of Melia azadirachia on larval development and reproduction parameters of Spodoptera littoralis (Boisd.) and Agrotis ipsilon (Hufn.) (Lepidoptera: Noctuidae). Anzeigerur Schadlingskunde, Pflanzenschute. 
التأثثرات البيولوجية والسمية لإثنان من المبيدات الحشرية الحيوية وأربعة مستخلصات نباتية على يرقات دودة ورق القطن أسبودبترا ليتورالس (الليليات : حرثفية الأجنحة)

\section{صبحى عبد الظاهر محمود إسماعيل}

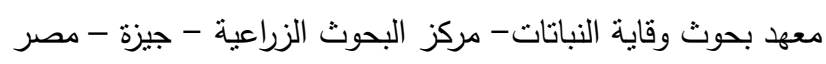

الملخص العربي

تم تقييم التأثير البيولوجى والسمية الابادية لمبيدين حشريين حيوبين مشتقين من بكتريا الباسيلس ثوارنجس وأربعة مستخلصات نباتية وهى : كوخيا أندكبا (قضقاض) ، كوركوما زوداريا (الكركم) (MVPa and MVPc)

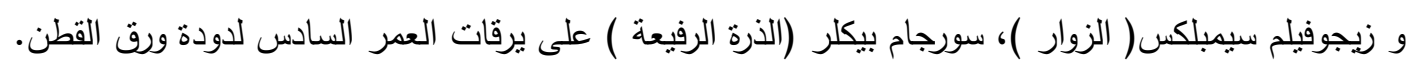

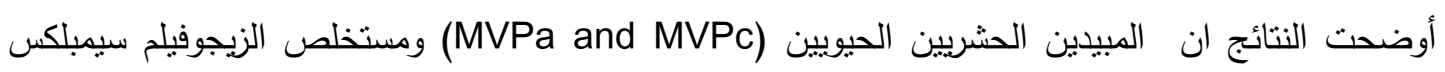

(الزوار )، هى الأكثر فعالية في السمية مقارنة بفاعلية باقى المستخلصات النباتية .

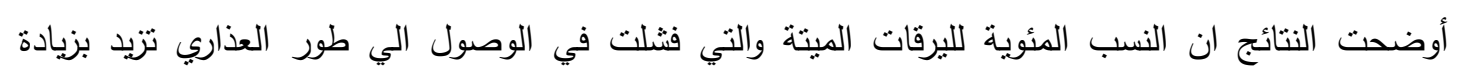
التركيزات المعاملة. في حين أن النسب المئوية للتعذير وخروج الحشرات الكاملة تزيد بزيادة التركيزات المختلفة لأنة للمعاملات. وقد لوحظ النتوهات الخلقية في العذاري والحشرات الكاملة المنتجة من اليرقات المعاملة الحية . 